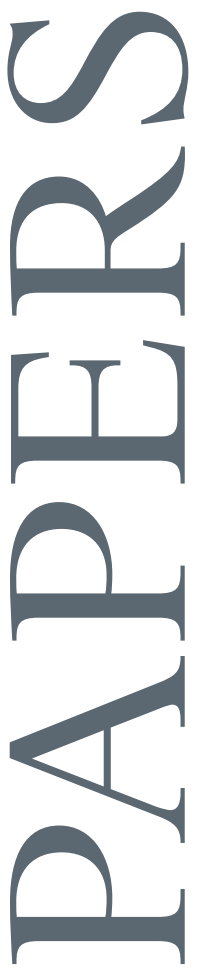

EAST-WEST CENTER WORKING PAPERS

Economics Series

No. 131, August 2012

Global Technology Sourcing in China's Integrated Circuit Design Industry: A Conceptual Framework and Preliminary Findings

Dieter Ernst and Barry Naughton

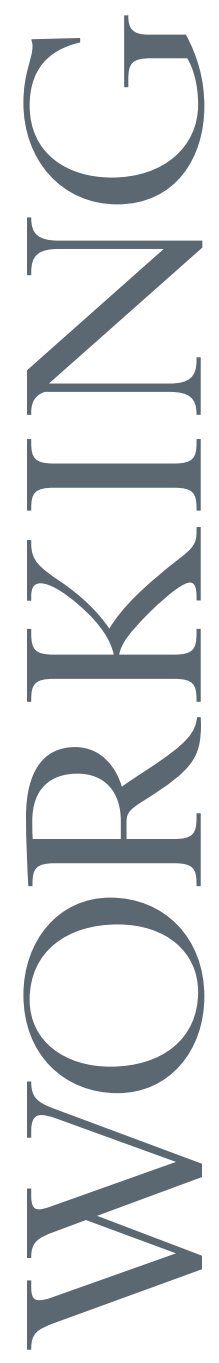

Je $\frac{\text { E A S T - W E S T C E N T E R }}{\text { COLlaboration • EXPertise - LeAdership }}$ 


\title{
Global Technology Sourcing in China's Integrated Circuit Design Industry: A Conceptual Frame- work and Preliminary Findings
}

\author{
Dieter Ernst and Barry Naughton
}

East-West Center Working Papers is an unreviewed and unedited prepublication series reporting on research in progress. The views expressed are those of the author and not necessarily those of the Center. East-West Center Working Papers are circulated for comment and to inform interested colleagues about work in progress at the Center.

Working Papers are available online for free at EastWestCenter.org/ewcworkingpapers. To order print copies ( $\$ 3.00$ each plus shipping and handling), contact the Center's Publication Sales Office.

The East-West Center promotes better relations and understanding among the people and nations of the United States, Asia, and the Pacific through cooperative study, research, and dialogue. Established by the US Congress in 1960, the Center serves as a resource for information and analysis on critical issues of common concern, bringing people together to exchange views, build expertise, and develop policy options.

The Center's 21-acre Honolulu campus, adjacent to the University of Hawai'i at Mānoa, is located midway between Asia and the US mainland and features research, residential, and international conference facilities. The Center's Washington, DC, office focuses on preparing the United States for an era of growing Asia Pacific prominence.

The Center is an independent, public, nonprofit organization with funding from the US government, and additional support provided by private agencies, individuals, foundations, corporations, and governments in the region.

\section{EastWestCenter.org/publications}

Publication Sales Office| East-West Center 1601 East-West Road | Honolulu, Hawai'i 96848-1601

Tel: 808.944.7145 | Fax: 808.944.7376

EWCBooks@EastWestCenter.org
Dr. Dieter Ernst, East-West Center senior fellow, is an authority on global production networks and R\&D internationalization in hightech industries and on industrial and innovation policies in China, the US and emerging economies, with a focus on standards and intellectual property rights. He serves as scientific advisor to the US National Academies, governments, private companies and international institutions. Publications include Indigenous Innovation and Globalization: The Challenge for China's Standardization Strategy (2011) [now published in Chinese]; A New Geography of Knowledge in the Electronics Industry? Asia's Role in Global Innovation Networks (2009); “China's Emerging Industrial Economy-Insights from the IT Industry," (2008, with B. Naughton); "Global Production Networks, Knowledge Diffusion and Local Capability Formation," (2002, with Linsu Kim); International Production Networks in Asia: Rivalry or Riches? (2000).

Dr. Barry Naughton, professor of economics at the Graduate School of International Relations and Pacific Studies (IR/PS) of the University of California, San Diego, is one of the world's top experts on the Chinese economy. His book The Chinese Economy: Transitions and Growth (MIT Press 2007) has been translated into Chinese and Korean. Naughton has published extensively on four interrelated areas: market transition; industry and technology; foreign trade; and Chinese political economy. His first book, a pioneering study of Chinese economic reform, Growing Out of the Plan: Chinese Economic Reform, 1978-1993 (Cambridge University Press, 1995) won the Masayoshi Ohira Memorial Prize. Naughton has consulted extensively for the World Bank, as well as for corporate clients. He is a member of the Council on Foreign Relations and is a non-resident fellow of the Brookings Institution in Washington, DC.

A first draft of this paper has been presented at the international conference on China's High-Technology Trade and Investment with Major Partners, cosponsored by SITC/University of California Institute of Conflict and Cooperation (IGCC) and the Stockholm International Peace Research Institute (SIPRI), La Jolla, California, July 23 and 24, 2012.

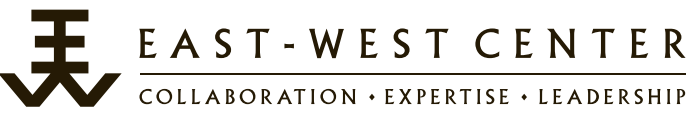




\title{
Global Technology Sourcing in China's Integrated Circuit
}

\author{
Design Industry
}

\author{
A Conceptual Framework and Preliminary Findings ${ }^{1}$
}

by

Dieter Ernst and Barry Naughton

\begin{abstract}
The paper examines the role of global technology sourcing, and its drivers and impacts in China's integrated circuit (IC) design industry. IC design is one of the priority targets of China's innovation policy, as codified especially in the "Strategic Emerging Industries" initiative. At the same time, however, China's IC design industry is deeply integrated into the vertically disintegrated global semiconductor industry, through markets, investment and technology. The paper highlights a fundamental challenge for China's innovation strategy: How can China reconcile its primary objective of strengthening indigenous innovation with the benefits that it could reap from its deep integration into international trade and into global networks of production and innovation?

We show that the process of global technology sourcing is changing in important ways as it becomes possible to "source" technological services in an increasingly fine division of the value chain, even compared to what was possible a few years ago.

The paper describes how globalization has transformed the distribution of scientific and technical knowledge; explores possible effects on technology sourcing; and examines the tension between these global changes and China's indigenous innovation policy. Focusing on IC design for wireless communications, the most dynamic part of China's country's IC design industry, we examine how changes in markets and technology create new strategic opportunities for Chinese IC design companies, and discuss tentative findings of case study research.

Global technology sourcing describes a small but important segment of China's innovation system that is very different from the government-sponsored innovation of the strategic emerging industries and "indigenous innovation." This raises an important policy question: Can China combine the benefits of both innovation strategies?
\end{abstract}

\footnotetext{
${ }^{1}$ A first draft of this paper has been presented at the international conference on China's High-Technology Trade and Investment with Major Partners, cosponsored by SITC/University of California Institute of Conflict and Cooperation (IGCC) and the Stockholm International Peace Research Institute (SIPRI), La Jolla, California, July 23 and 24, 2012.
} 


\section{Introduction}

The study of "technology transfer" has produced a rich and valuable literature, but the term "technology transfer" can also be somewhat misleading. Technology "transfer" puts the primary focus on the technology owners (or holders); the determinants of their strategies; and the impact of these on "access to technology" by the recipient country. We prefer instead to talk about "technology sourcing" strategies of technology-using companies and countries that involve search, absorption, learning, diffusion, as well as innovations - especially incremental innovations - that convert ideas, inventions, and discoveries into new products, services, processes, and business models.

We apply this framework to China's integrated circuit (IC) design industry and examine the role of global technology sourcing, its drivers and impacts. IC design is one of the priority targets of China's innovation policy, as codified especially in the SEI initiative. At the same time, however, China's IC design industry is deeply integrated into the vertically disintegrated global semiconductor industry, through markets, investment and technology. The study of global technology sourcing in China's IC design industry thus allows us to explore a fundamental challenge for China's innovation policy: To what degree is indigenous innovation compatible with globalization?

Specifically, the paper contributes to the literature in the following ways: First, we show that the process of global technology sourcing is changing in important ways as it becomes possible to "source" technological services in an increasingly fine division of the value chain, even compared to what was possible a few years ago. Second, the paper introduces a conceptual framework for analyzing the great variety of technology sourcing arrangements that characterize a highly globalized industry like IC design.

Third, the paper examines stages of chip design where global technology sourcing is likely to be critical for Chinese fabless IC design companies. Fourth, a distinction of different types of technology sourcing arrangements, such as licensing of inventions, contractual arrangements for training, knowledge sharing (e.g. the source code for IC design, software and system platforms), as well as the development of applications allows us to make some fresh observations about the nature of intellectual property protection, standardization, global technology sourcing, and the innovation process. 
The paper focuses on global technology sourcing in China's IC design industry for wireless communications. The paper proceeds from the general to the specific: we begin with global trends and conclude with a description of the business and technology strategies of three Chinese companies. Part One of the paper describes the broad patterns through which globalization has transformed the distribution of scientific and technical knowledge; explores possible effects on technology sourcing; and examines the tension between these global changes and China's indigenous innovation policy. Part Two introduces a framework for analyzing the industrial value chain of the semiconductor industry (with a focus on IC design), highlighting the role of providers of EDA tools, design IP building blocks, fab equipment, and materials, as well as foundry services and assembly and testing services.

Part Three identifies possible drivers of global technology sourcing. We focus on IC design for wireless communications, one of the most dynamic industries in the world, and arguably the most dynamic part of China's country's IC design industry. We examine how changes in markets and technology create new strategic opportunities for Chinese IC design companies. We then explore multiple challenges that Chinese IC design firms are facing when they attempt to upgrade and scale up their operations in order to penetrate new markets for higher-end products and processes. In Part Four, we describe diverse approaches to global technology sourcing by one Chinese smart phone vendor and two Chinese wireless IC design firms.

\section{Part One - Globalization transforms technology sourcing and this has implications for China's innovation policy}

Reflecting the globalization of markets and production, technology transfer increasingly cuts across national borders and links technology owners and users in countries that differ in their stage of development and in their economic institutions, and hence in their capacity to absorb and develop technology. International technology transfer has long been characterized by two basic facts: First, despite an increase in the geographic dispersion of $\mathrm{R} \& \mathrm{D}$, scientific and technological knowledge remains highly concentrated. Second, the commercialization of technology typically imposes restrictions - legal and other - on the free communication of knowledge. 
Yet the conditions of international technology transfer are also changing fast: the process of global technology sourcing is changing in important ways as it becomes possible to "source" technological services in an increasingly fine division of the value chain, even compared to what was possible a few years ago. (We discuss these transformations further below.)

The changes in the global sourcing environment pose significant challenges to China's innovation policy. On the one hand, Chinese innovation policy since 2005 has strongly stressed the importance of "indigenous innovation." While indigenous innovation does not imply a closed-door approach to innovation, it lays heavy stress on increasing domestic inputs into the R\&D process and on developing locally-owned intellectual property. Indigenous innovation was adopted as a policy in the Medium and Long-term Plan for Science and Technology Development (2006-2020) [hereafter, MLP], which explicitly states that "experience shows that developed countries are unwilling to transfer core technologies to China." Thus, indigenous innovation was promoted as a domestically controlled alternative for developing core technologies that are (asserted to be) unavailable on the international marketplace.

On the other hand, Chinese industry is deeply integrated into global industry. In 2011, foreign-invested enterprises produced $52.4 \%$ of China's exports. $44 \%$ of exports were produced under so-called "processing trade" arrangements, in which imported inputs are assembled into exports, which is an index of China's high degree of insertion into global production networks ${ }^{2}$. But China's integration goes far beyond this, since Chinese industry is linked to multinational corporations by investment and cross-national research networks as well. Today, China is the largest 'net importer' of R\&D, and it is the third most important offshore R\&D location for the 300 top R\&D spending multinationals, after the United States and the United Kingdom. ${ }^{3}$ As a result, the share of China's high tech exports by foreign-invested enterprises (FIEs) rose from $79 \%$ in 2002 to $82 \%$ in $2010 .^{4}$

\footnotetext{
${ }^{2}$ General Administration of Customs, PRC, "2011 Trade by Trade Regime," accessed at http://www.customs.gov.cn/publish/portal0/tab44604/module109000/info353199.htm

${ }^{3}$ Ernst, D., 2011,Testimony To the U.S.-China Economic and Security Review Commission Hearing on China's Five Year Plan, Indigenous Innovation and Technology Transfers, and Outsourcing June 15, 2011, page 6

${ }^{4}$ Congressional Research Service, China's Economic Condition, June 2012, page 11
} 
It is true that through the present, China has typically participated in global production networks by providing low-value assembly services that intensively use lowcost labor. From garments to assembly of laptop computers, relatively low-wage Chinese workers earn a small portion of the value of export products. Case studies of particular products - strikingly including the iPhone - confirm that China earns a small proportion of the value of sophisticated exports, often less than $5 \%{ }^{5}$. Thus, conclusions based on data about the share of high-technology exports among China's exports are highly misleading (or even more so, about China's total high technology exports in comparison to the high technology exports of the US) ${ }^{6}$.

Whether China's initial concentration in low-tech assembly and export processing means that upgrading is difficult or impossible is a question for empirical research, and much depends on conditions in individual industrial sectors. The close ties with multinational firms and global markets suggests a path of technological upgrading that would rely on close partnering with multinationals, development of sub-contracting networks, and gradual "learning by doing." To a certain extent, indigenous innovation represents a rejection of this technology development path, and an assertion that only a stronger domestic effort can really succeed in developing core technological capabilities. The fact that China's technology planners are willing to risk policies that may weaken the strong existing international links displays their deep conviction that China is locked into a low-technology position in global value chains that is difficult to break out of, and that global firms will not willingly share core technologies. Thus, a fundamental challenge for China's innovation policy is: To what degree is indigenous innovation compatible with globalization?

It should be stressed that, intellectually at least, "indigenous innovation" policies do not advocate closed-door innovation or technological autarchy. Global technology sourcing and the integration of acquired technologies into new technological solutions are explicitly mentioned in the MLP as types of indigenous innovation. However, the plan

\footnotetext{
${ }^{5}$ See, for instance, Ali-Yrkko, J. et al, 2011, Who Captures Value in Global Supply China? Case Nokia N95 Smartphone, ETLA Discussion Papers No. 1240, 28 February, The Research Institute of the Finnish Economy, Helsinki

${ }^{6}$ For an analysis of the impact of fragmentation on trade statistics, see Stehrer, R., N. Foster and G. de Vries, Value Added and Factors in Trade. A Comprehensive Approach, World Input-Output Dababase Working Paper \# 7, April, pages 1-22
} 
also sets as a target the increase in domestic $\mathrm{R} \& \mathrm{D}$ expenditures relative to expenditure on technology import, which is unlikely to be compatible with a pure cost minimization strategy. Moreover, the strong stress on indigenous innovation undoubtedly discourages firms in practice from deep partnership strategies. In any case, the actual outcome, as Figure 1 shows, is that China has dramatically increased domestic outlays for R\&D, while expenditures for technology import have grown much more slowly. Between 2000 and 2010, domestic R\&D increased by nearly a factor of ten (in dollar terms, converted at exchange rates), while technology import expenditures increased by about $40 \%$.

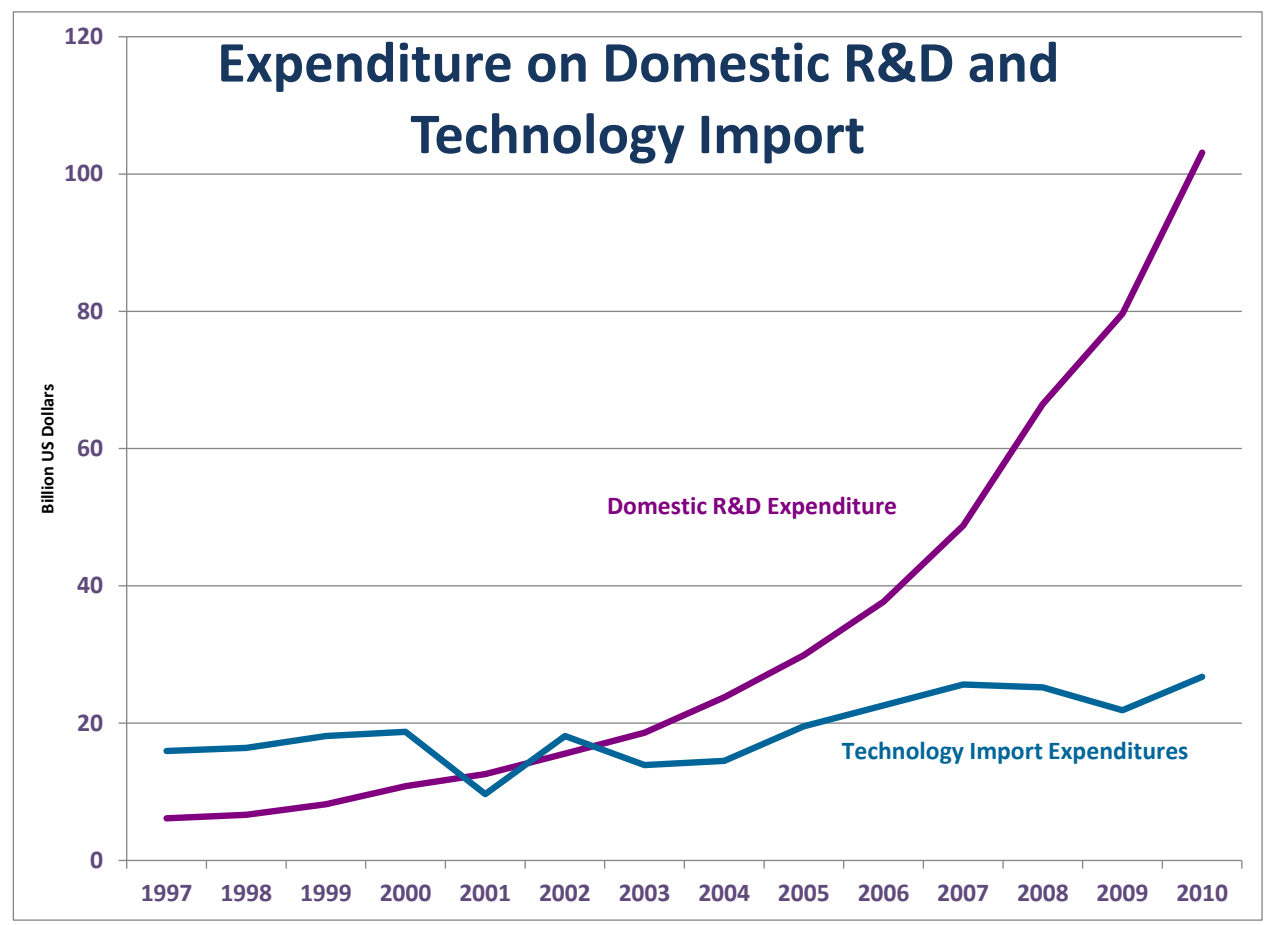

The IC design industry exemplifies the dilemma that China faces. IC design is one of the priority targets of China's innovation policy, as codified most recently in the Strategic Emerging Industries (SEI) plan just published. ${ }^{7}$ Moreover, Chinese technology planners have studied value chains enough to decide that the key to successful planning is to nurture the development of every stage of the value chain. They believe that the creation of an alternative Chinese 3G telecom standard, TD-SCDMA was a success made possible by their decision to nurture base station producers, handset manufacturers, telecom operators, and chip manufacturers simultaneously. Their development strategy,

7 国务院关于印发 “十二五” 国家战略性新兴产业发展规划的通知 [The State Council Notification on the Long-term Development Plan for Strategic Emerging Industries during the $12^{\text {th }}$ Five Year Plan], 国发 〔2012〕 28 号. July 7, 2012. 
then, assumes the need to support domestic development at every stage of the value chain, and this is explicit in the IC sector in the SEI plan ${ }^{8}$.

At the same time, however, China's IC design industry is deeply integrated into the global semiconductor industry, through markets, investment and technology. China's integration into the global industry depends precisely on the vertical dis-integration of the global IC industry, including the IC design industry. The process of dis-integration started decades ago, as the semiconductor industry re-organized around so-called "fabless IC design companies" who sent their designs to be made into silicon-based products at "pure play fabs" (IC factories). While a few of the largest integrated device manufacturers, such as Intel and Samsung, continued to combine IC design and manufacture (and thrive), most firms moved to the disaggregated model. This disintegration was also associated with a shift of the industry toward Asia, as the most important pure-play fabs were in Asia, and especially in Taiwan. ${ }^{9}$ This long-term disintegration of the industry has recently accelerated, as we show later.

Recently, the whole value chain related to mobile phone handsets has been transformed, with the center of gravity moving to Asia, and especially China. For instance, there are three times as many mobile handset subscribers in China as in the US (more than 1 billion relative to 331.6 million). ${ }^{10}$ China now accounts for more than one sixth of the world's mobile subscribers. ${ }^{11}$ Most significantly, China has recently emerged as the largest market for smart phones - with $22 \%$ of global smart phone shipments in Q4 2011, China has now overtaken the US which accounts for $16 \% .^{12}$

The recent further dis-integration in the semiconductor value chain has substantially reduced entry barriers for newcomers like Chinese IC design firms. As the CEO of one of the most important Chinese IC design companies recently told us, "the

\footnotetext{
${ }^{8}$ For semiconductors, the initial goal was to "....significantly increase the self-sufficiency ratio to over 70 percent for integrated circuits used for information and national defense security, and to over 30 percent for integrated circuits used in communications and digital household appliances.... We should basically achieve self-sufficiency in the supply of key products". Ministry of Information Industry, August 29, 2006. ${ }^{9}$ For the economics of global vertical disintegration in IC design, see Ernst, D., 2005, "Complexity and Internationalization of Innovation: Why is Chip Design Moving to Asia?", International Journal of Innovation Management: and Ernst, D., 2005, "Limits to Modularity - Reflections on Recent Developments in Chip Design", Industry and Innovation.

${ }^{10}$ CTIA, November 2011

${ }^{11}$ ITU, 2012

${ }^{12}$ Canalys, Q1 2012
} 
availability of IC design tools, semiconductor fab services, and open-source smartphone software [Android] allows Chinese firms to circumvent their weak spots and develop their strengths in hardware, IC design, and integration."13

In other words, fundamental changes in global end user markets for wireless communication chips, combined with recent advances in the organization of the global semiconductor industry have opened up new possibilities of an increasingly fine division of the IC design value chain. One of these possibilities is the space for Chinese firms to introduce new innovative and disruptive business models that foster and reward significant innovation in IC design and system integration. This raises a number of important questions that need to be addressed head on in current debates on China's innovation policy: Will intensifying competition during the second half of 2012 generate a wave of such innovations to break into the Chinese telecom market? What forces could drive this emerging innovation push in China's IC design industry for wireless communications? Is this innovation push sustainable? How important a source for those innovations is global technology sourcing relative to home-made inventions? And what are the implications for global issues relating to intellectual property rights, standardization, and economic development?

To explore these issues we need to describe in greater depth how globalization is changing technology sourcing in the IC design industry in general, and in IC design for wireless communications in particular. This paper is a first attempt to develop such a research agenda.

\section{A Framework for Analyzing Technology Sourcing in the Semiconductor Value Chain, with a Focus on IC design}

This part describes the participants in the semiconductor value chain, and their specific role as technology holders and technology users. [See slide 1] Of the almost 20 participants in the semiconductor value chain, the paper highlights the role of providers of EDA tools, design IP building blocks, fab equipment, and materials, as well as foundry services and assembly and testing services. Drawing on our first round interview notes, a few illustrative examples are described of technology sourcing arrangements of Chinese IC design companies.

\footnotetext{
${ }^{13}$ Authors' interviews in China's IC design industry, June 21 to July 2, 2012.
} 
In a second step, we look at information flows across the Semiconductor value chain, and distinguish between information flows within the supply chain, and information flows within the demand chain. This distinction allows us to bring into our analysis as well OEMs and contract manufacturers, and possibly also distributors. [See slide 2]

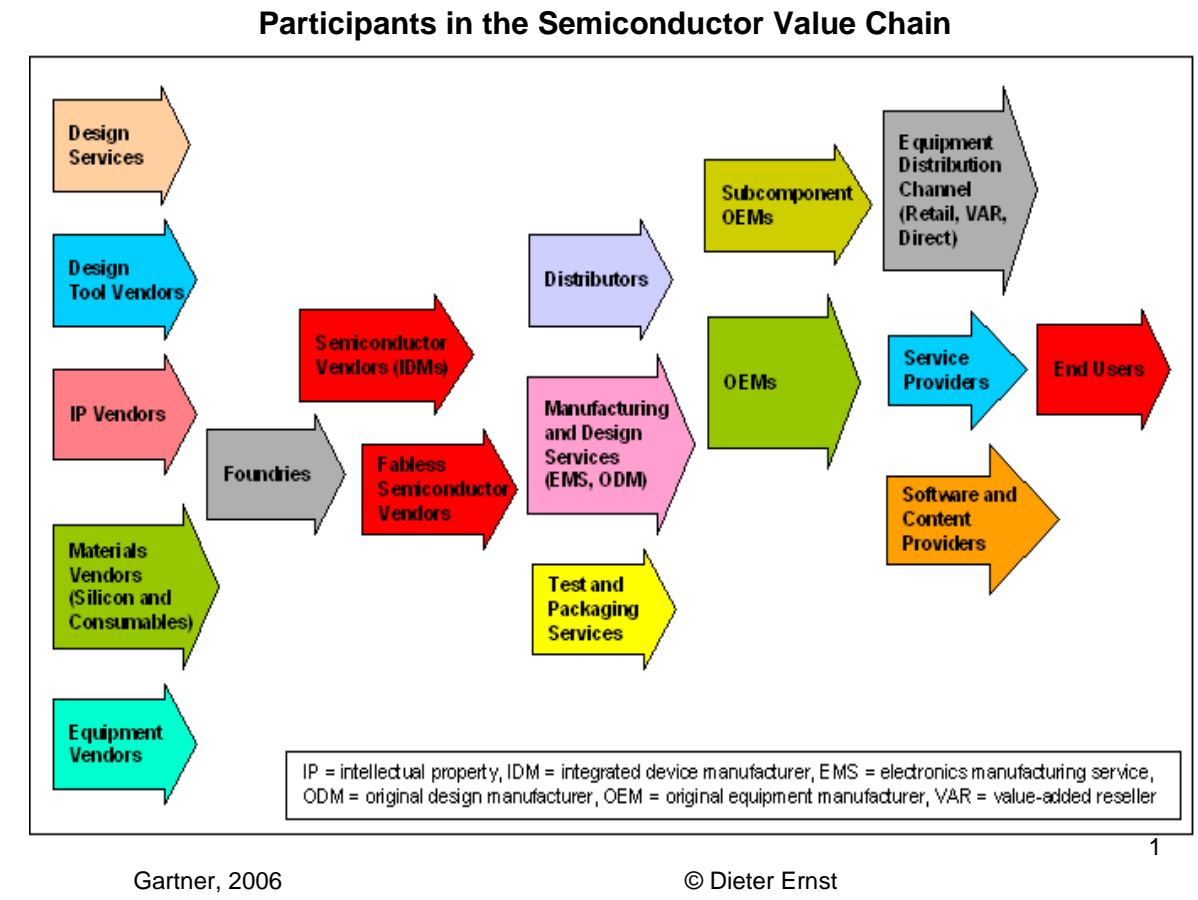




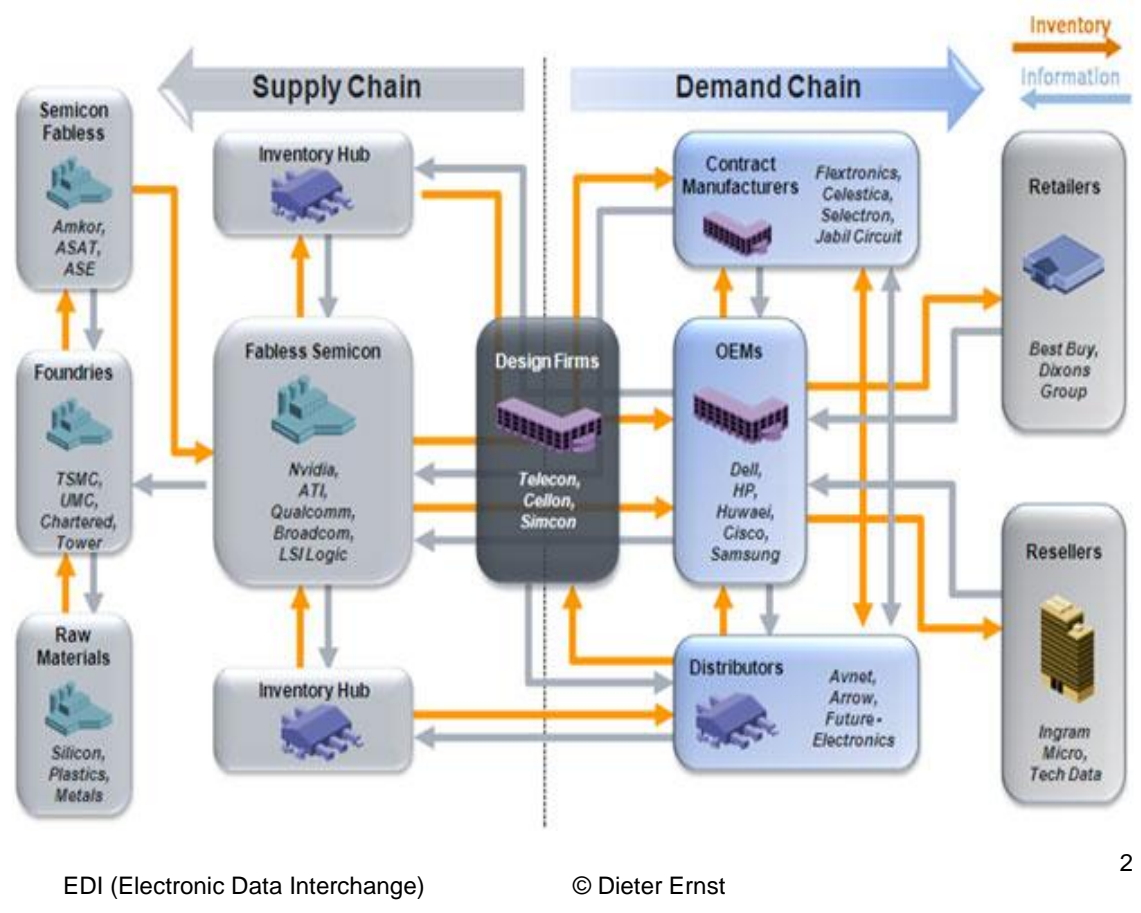

We then shift the focus of our analysis to IC design. The following slide 4 presents a typical chip design flow chart to distinguish stages of chip design all the way from circuit design to fabrication, packaging and assembly and final system test and debugging. We can use this flow chart to identify areas where Chinese IC design companies need to engage in technology sourcing. [slide 4]. 


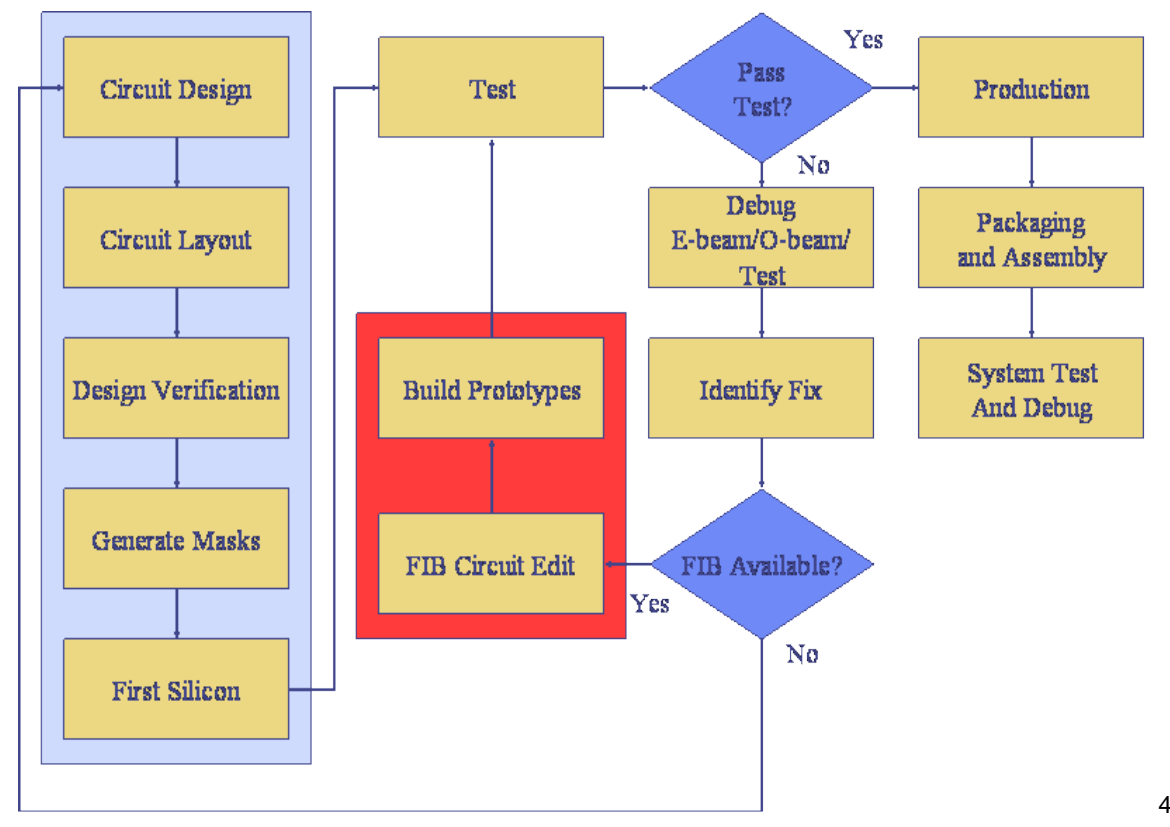

Slide 5 demonstrates how significant the scope is for technology sourcing across all stages of the development cycle of an integrated circuit. The slide identifies 13 different types of IC design support services that Chinese IC design companies in principle can contract out to external suppliers. These services can be provided by individual specialized service providers, many of them located in Taiwan. Or, as indicated in slide 5, these services can all be consolidated in one IC design service package provided for instance by a foundry like TSMC. The analysis will have to establish the pros and cons of fragmented versus integrated provision of these IC design services. 


\section{IC Development Cycle Stages}

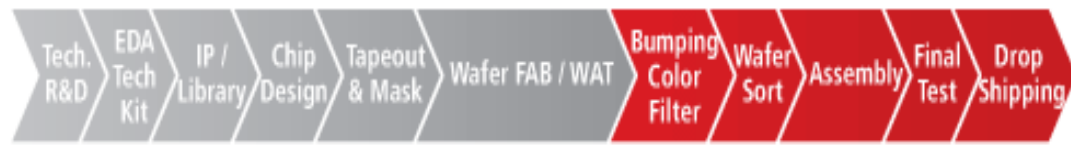

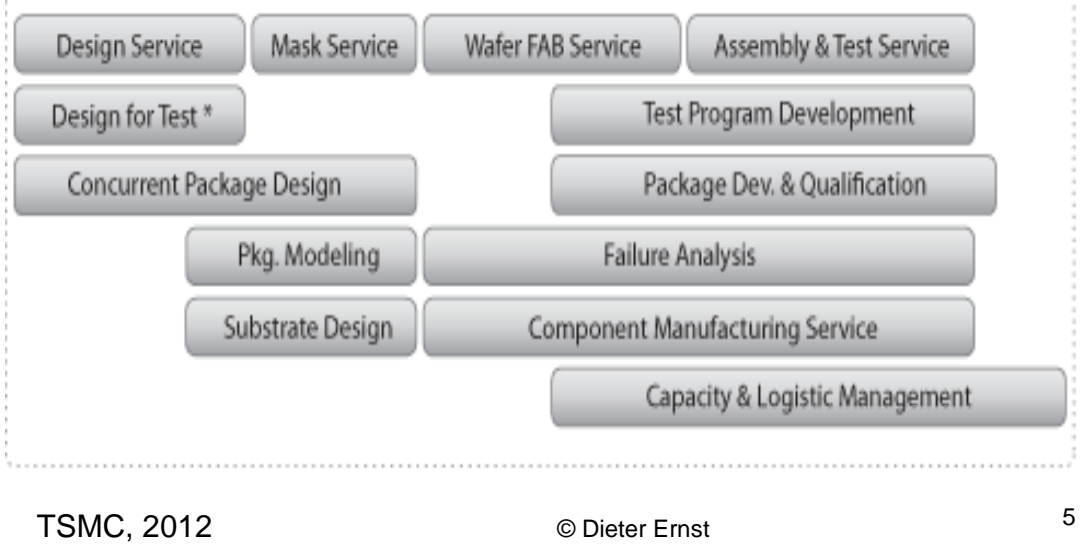

\section{Part Three IC design for Wireless Communications -Changes in Markets and Technology as Drivers of Global Technology Sourcing by Chinese firms}

In order to identify possible drivers of global technology sourcing, part three provides an analysis of the evolution of IC design for wireless communications in China, the most dynamic part of the country's IC design industry. Not only is China the biggest market for mobile handsets, with China Mobile being the world's biggest carrier by a margin. Since 2011, China has also emerged as the biggest market for smart phones, ahead of the US, and third generation (3G) mobile telecommunications is finally taking hold. In addition, massive investments are underway to accelerate the build-up of China's $4 \mathrm{G}$ network infrastructure.

Together, these changes in markets and technology have created new strategic opportunities for Chinese IC design firms to upgrade their product portfolios, process technologies and business models. To utilize this potential, and to develop effective upgrading strategies will not be easy for Chinese firms, given their so far limited management and innovation capabilities.

The analysis reviews the current status of China's IC industry and discusses changes in markets and technology that are providing strategic opportunities for Chinese IC design companies to expand their role in mobile handsets and especially smart phones. 
We then explore multiple challenges that Chinese IC design firms are facing when they attempt to upgrade and scale up their operations in order to penetrate new markets for higher-end products and processes.

We argue that, in order to cope with those 'upgrading challenges', Chinese IC design companies are forced to rely on global technology sourcing across the semiconductor value chain. Our first found of interviews show that leading Chinese IC design firms are all relying quite extensively on global technology sourcing. But we also find very different approaches to global sourcing. To some degree, this reflects the current state of experimentation - after all, these developments are very new. However, the diversity of approaches may also indicate that there is no one-best way of organizing global technology sourcing. This raises an important question for future research: Do Chinese IC design firms in the wireless communications industry have discretion to develop their own idiosyncratic forms of technology sourcing?

\section{Current status of China's IC design industry}

IC design has been one of the favorite poster childs of China's indigenous innovation policy. And it certainly fared better than most of China's semiconductor industry. Growing from $\$ 178 \mathrm{M}$ in 2001 to $\$ 5.4 \mathrm{~B}$ in 2010, IC design experienced a CAGR of more than $46 \%$. In fact, IC design was the fastest growing segment of China's semiconductor industry ${ }^{14}$. In 2010, China's IC design dollar revenues grew by $36 \%$, exceeding the worldwide market growth rate of $32 \%$. In the same year, China's fabless IC design companies had a share of $7 \%$ in the $\$ 74 \mathrm{~B}$ worldwide fabless IC design industry - up from a 1\% share in 2001 and a 4\% share in 2004.

Despite this rapid growth, Chinese IC design firms continue to play second fiddle. Insufficient size is an important weakness. In fact, the combined revenues of the top ten Chinese IC design companies of $\$ 1.57 \mathrm{~B}$ is much lower than the individual results posted by each of the top five global fabless companies ${ }^{15}$.

Key weaknesses that constrain the growth of China's IC design industry include a narrow focus on consumer products, especially low- and middle-end products such as

\footnotetext{
${ }^{14} \mathrm{PwC} 2011$, China's impact on the semiconductor industry...

${ }^{15}$ China's Fablessss Profile, EE Times Confidential Special Report 2011
} 
color TVs, sound systems, clocks, electronic toys, small home appliances and remote controls. As long as China depends on these mature and relatively standardized products, this will constrain China's R\&D and capability development in IC design.

In addition, while China's IC design industry has improved its design capabilities, it still lags substantially behind the US, Japan, Taiwan and Korea, in terms of process technology and design line width. Furthermore, China lacks strong domestic suppliers of EDA tools and software and domestic licensors of IC design-related intellectual property.

China's patent applications for semiconductors show that its innovative capacity is improving, but China still has a long way to go to catch up with the US. China's share of worldwide semiconductor technology-focused patents published each year increased from $13.4 \%$ in 2005 to $21.6 \%$ in 2009 - and was forecast to reach 33\% in 2011. More significantly, China's share of semiconductor patents that are being first issued in China has grown from zero in 2005 and 2006 to $24.1 \%$ in $2009^{16}$.

Among leading Chinese IC design companies are affiliates of China's leading telecom equipment vendors Huawei (HiSilicon Technologies) and ZTE (Shenzhen ZTE Microelectronics); an affiliate of the Haier Group (Haier Beijing IC Design Company); and Shanghai Belling (which until March 2010 was a joint venture with Alcatel as the second largest share holder with a $25.64 \%$ share). Of particular interest are independent fablesss design companies like RDA (with a focus on RF ICs), Spreadtrum Communications (a supplier of chipsets of China's TD-SCDMA 3G handsets), Nationz Technologies (SOC and RF design for information security telecommunication and consumer devices), and Availink (focus on digital TV, multimedia and communications).

But even these Chinese industry leaders are well behind the global IC design industry leaders. Take productivity. Of the five Chinese IC design companies that were reported in the Global Semiconductor Alliance (GSA) Global Financials Report in 2009, only one, Spreadtrum Communications with 674 employees, had a sales per employee productivity level that was more than one-third that of the GSA's worldwide 183 fablesss

\footnotetext{
${ }^{16}$ Derwent Worldwide Patent data quoted in Ernst, D., 2012, China's Position in the Global Semiconductor Value Chain - Still Playing Second Fiddle?, manuscript, East-West Center, Honolulu
} 
company 2009 average of US $\$ 475,000$ per employee ${ }^{17}$. The company achieved sales per employee of only US\$156,000 in 2009, up from US\$141,000 in 2008.

In short, China's IC design industry still has a long way to go to catch up with the leading IC design industries in the US, Japan, the EU, Taiwan and Korea. There is no Chinese IC design company in sight that might be able to challenge current global industry leaders. China's persistent innovation gap in IC design implies that Chinese firms continue to need access to foreign technology. Hence, global technology sourcing across the semiconductor value chain is of critical importance for reaping the strategic opportunities that current changes in markets and technology are creating in wireless communications.

\section{Strategic opportunities in the wireless communications market}

Since the bursting of the Internet bubble at the turn of the century, wireless communications is an industry in turmoil, with tectonic shifts in markets and technology.

Here are a few proxy indicators that demonstrate the tsunami-like character of these changes $^{18}$. In 2012, Total Global Mobile Revenues have reached \$1.5 Trillion, over $2 \%$ of Global GDP. Mobile Operator Profits have more than doubled over the last 10 years. However, the wealth is not divided evenly, with Asia's share having tripled at the expense of Europe whose profit share has declined by $50 \%$.

By the end of 2011, the global mobile subscriptions exceeded 6 Billion. The first 1 billion took over 20 years and this last one took only 15 months. The primary growth drivers are India and China which are cumulatively adding 75M new subscribers every quarter. China became the first country to eclipse the 1 billion mark in March 2012. India is likely to arrive at the milestone by early 2013.

However, while mobile subscriber growth is fastest in Asia, revenue growth still remains focused on the US. In 2011, the US accounted for only six \% of worldwide new mobile subscriptions. Yet, in the same year, the US reported $21 \%$ of the global service revenues, $26 \%$ of the mobile data revenues, and $27 \%$ of the global capital expenditures.

\footnotetext{
${ }^{17}$ Global Semiconductor Alliance (GSA), 2010, Global Semiconductor Financial TRACKER http://www.gsaglobal.org/login_special.asp?redirect=/publications/financials/0904/index.asp

${ }^{18}$ Sources include author's interviews; Mobithinking.com; Portico Research Mobile Factbook 2012; ITU; Canalys; Strategy Analytics; iSuppli; McKinsey; PwC; and Gartner Dataquest.
} 
Despite the growing importance of Asian markets, the US market continues to matter, especially for the higher-end and more profitable market segments.

Of particular importance for IC design is that mobile devices are now exceeding traditional computers in unit sales and revenues. In 2011, for instance, 1,551.4 M handsets were sold worldwide (compared to $355.2 \mathrm{M}$ computers), up 14\% compared with 2010. And the share of smart phones in global handset sales has increased now to $32 \%$, up from $19.3 \%$ in 2010. Most importantly, China is now the largest market for smart phones - with 22\% of global smart phone shipments in Q4 2011, China has overtaken the US which accounts for $16 \%{ }^{19}$. With global smart phone shipments of 146 million, this means that 32 million smart phones have been sold in China during Q4 2011. As a result, the size of the Chinese smart phone market is now large enough to enable minimum economies of scale and scope for leading Chinese IC design firms.

In addition, entry barriers to IC design for wireless communications are drastically declining, as vertical specialization has penetrated deeper and deeper into the global semiconductor value chain. As shown in part Two, fablesss IC design companies in China can now source technology and management support services from multiple sources, but especially from providers of IC design building blocks, EDA and testing tools, and foundry services. For instance, the availability of design IP building blocks through ARM and many other companies like for instance Tensilica, enables Chinese IC design firms companies to reduce their R\&D investments which allows for a substantial reduction in their overheads. Chinese fabless IC design companies can now better focus on speed-to-market and reduce $\mathrm{R} \& \mathrm{D}$ cycles, enabling them to respond faster to the required yearly changes in IC design.

Furthermore, China-based fablesss IC design companies can source complementary intellectual property and management capabilities through the acquisition of competitors. Prominent recent examples that we observed during our June 2012 China interviews, include RDA's acquisition of Coolsand, and, most importantly, Mediatek's acquisition of M-Star. ${ }^{20}$

\footnotetext{
${ }^{19}$ Canalys, Q1 2012

${ }^{20}$ While both MediaTek and M-Star are Taiwanese companies, their prirmary focus is the China market. The authors' future research will examine possible implications of these acquisitions for global technology sourcing.
} 
A particular important enabling factor for the entry of Chinese IC design firms has been the emergence of open-source smart phone software. This enables Chinese IC design firms to concentrate on hardware design first, before developing and catching-up in software design capabilities.In the first quarter of 2012, Google's Android mobile operating system took almost $77 \%$ of China's smart phone sales ${ }^{21}$. At the same time, the availability of mature and inexpensive chip set solutions provided by Taiwan's Mediatek has furthered lowered the entry barriers, enabling China's whitebox ("Shanzhai") makers to penetrate into China's thriving budget smart phone market. This has given rise to a renaissance of China's Shanzhai sector, but this time the focus is on incremental innovations in low-cost smart phones.

As a result, a local ecosystem for budget smart phones is emerging that links IC designers, OEMs and Chinese customers (see slide 13). The primary focus is on the China market, and but increasingly other Asian emerging economies are becoming important targets.

\section{Grey Market Mobile Phone Supply Chain}
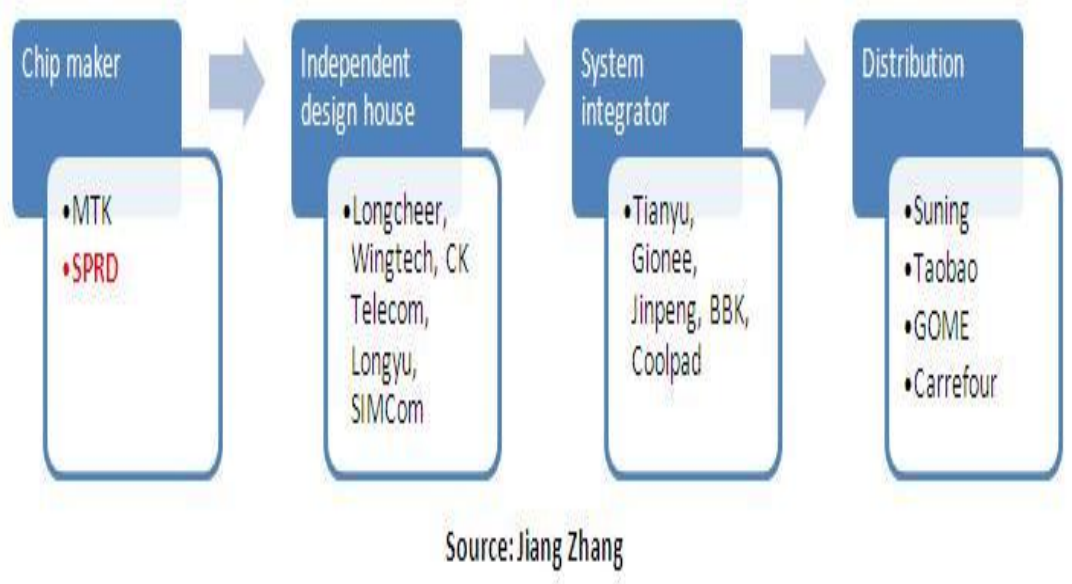

(C) Dieter Ernst

\footnotetext{
${ }^{21}$ Android's rapid rise has been at the expense of Nokia's Symbian operating system which in the first quarter of 2011 still accounted for almost $43 \%$ of China's smart phone sales, but fell to less than $12 \%$ in Q1 2012. A further sign of Nokia's decline in the China market is that it reduced its China workforce by $50 \%$ in June 2012.
} 
In short, fundamental transformations in the wireless communications industry have had important implications for the geographic location of fablesss wireless IC design. Following the pull of Asian markets, especially in China, there has been a move of such activities to Asia, and this has changed quite dramatically the global competitive landscape in this industry. Until only a few years ago, fablesss wireless IC design was dominated by around 20 companies, 10 from the US, 6 from Europe and and 4 from Japan ${ }^{22}$. Today, four leading companies in the $\mathrm{US}^{23}$ compete against a growing number of new contenders from Asia (outside of Japan), with one European company (ST-Ericsson) and one Japanese company (MegaChips ${ }^{24}$ ) left in the top global 25 list. As shown in slide 11, 8 of the top 25 fablesss IC suppliers in 2011 were from emerging Asia (with two from China). And ranked by growth, 10 companies from emerging Asia were among the top 25, with one Chinese company, Spreadtrum, displaying by far the fastest growth rate during 2011 (slide 12).

(c) Dieter Ernst

2011 Top 25 Fabless IC Suppliers (\$M)

\begin{tabular}{|c|c|c|c|c|c|c|c|c|c|}
\hline $\begin{array}{l}2011 \\
\text { Rank }\end{array}$ & $\begin{array}{r}2010 \\
\text { Rank }\end{array}$ & $\begin{array}{l}2009 \\
\text { Rank }\end{array}$ & Company & Headquarters & $\begin{array}{l}2009 \\
\text { (SM) }\end{array}$ & $\begin{array}{l}2010 \\
(\$ M)\end{array}$ & $\begin{array}{c}\% \\
\text { Change }\end{array}$ & $\begin{array}{l}2011 \\
(\mathrm{SM})\end{array}$ & $\begin{array}{c}\% \\
\text { Change }\end{array}$ \\
\hline $\begin{array}{l}1 \\
2 \\
3 \\
4 \\
5\end{array}$ & $\begin{array}{l}1 \\
2 \\
3 \\
6 \\
4\end{array}$ & $\begin{array}{l}1 \\
3 \\
2 \\
5 \\
6\end{array}$ & $\begin{array}{l}\text { Qualcomm } \\
\text { Broadcom } \\
\text { AMD } \\
\text { Nvidia } \\
\text { Marvell }\end{array}$ & $\begin{array}{l}\text { U.S. } \\
\text { U.S. } \\
\text { U.S. } \\
\text { U.S. } \\
\text { U.S. }\end{array}$ & $\begin{array}{l}6,409 \\
4,271 \\
5,403 \\
3,151 \\
2,690\end{array}$ & $\begin{array}{l}7,204 \\
6,589 \\
6,494 \\
3,575 \\
3,592\end{array}$ & $\begin{array}{l}12 \% \\
54 \% \\
20 \% \\
13 \% \\
34 \%\end{array}$ & $\begin{array}{l}9,910 \\
7,160 \\
6,568 \\
3,939 \\
3,445\end{array}$ & $\begin{array}{c}38 \% \\
9 \% \\
1 \% \\
10 \% \\
-4 \%\end{array}$ \\
\hline 6 & 5 & 4 & MediaTek & Tawan & 3,500 & 3,590 & $3 \%$ & 2,969 & $-17 \%$ \\
\hline $\begin{array}{c}7 \\
8 \\
9 \\
10\end{array}$ & $\begin{array}{c}7 \\
8 \\
9 \\
10\end{array}$ & $\begin{array}{c}7 \\
10 \\
8 \\
11\end{array}$ & $\begin{array}{l}\text { Xilinx } \\
\text { Altera } \\
\text { LSI Corp. } \\
\text { Avago }\end{array}$ & $\begin{array}{l}\text { U.S. } \\
\text { U.S. } \\
\text { U.S. } \\
\text { Singapore }\end{array}$ & $\begin{array}{c}1,699 \\
1,196 \\
1,422 \\
858\end{array}$ & $\begin{array}{l}2,311 \\
1,954 \\
1,616 \\
1,187\end{array}$ & $\begin{array}{l}36 \% \\
63 \% \\
14 \% \\
38 \%\end{array}$ & $\begin{array}{l}2,269 \\
2,064 \\
2,042 \\
1,341\end{array}$ & $\begin{array}{l}-2 \% \\
6 \% \\
26 \% \\
13 \%\end{array}$ \\
\hline 11 & 13 & 12 & MStar & Tawan & 838 & 1,065 & $27 \%$ & 1,220 & $15 \%$ \\
\hline 12 & $\begin{array}{l}11 \\
15\end{array}$ & $\begin{array}{l}13 \\
16\end{array}$ & $\begin{array}{l}\text { Novatek } \\
\text { CSR }\end{array}$ & Taiwan & $\begin{array}{l}819 \\
601\end{array}$ & $\begin{array}{c}1,149 \\
801\end{array}$ & $\begin{array}{l}40 \% \\
33 \%\end{array}$ & $\begin{array}{c}1,198 \\
845\end{array}$ & $\begin{array}{l}4 \% \\
5 \%\end{array}$ \\
\hline 14 & $\begin{array}{l}15 \\
12\end{array}$ & 9 & ST-Ericsson* & Europe & 1,263 & 1,146 & $-9 \%$ & 825 & $-28 \%$ \\
\hline 15 & 16 & 15 & Realtek & Taiwan & 615 & 706 & $15 \%$ & 742 & $5 \%$ \\
\hline 16 & 17 & 17 & HiSilicon & China & 572 & 652 & $14 \%$ & 710 & $9 \%$ \\
\hline 17 & 27 & 67 & Spreadtrum & China & 105 & 346 & $230 \%$ & 674 & $95 \%$ \\
\hline 18 & 19 & 19 & PMC-Sierra & U.S. & 496 & 635 & $28 \%$ & 654 & $3 \%$ \\
\hline 19 & 18 & 14 & Himax & Taiwan & 693 & 643 & $-7 \%$ & 633 & $-2 \%$ \\
\hline 20 & 21 & - & Lantiq & Europe & 0 & 550 & N/A & 540 & $-2 \%$ \\
\hline 21 & 33 & 30 & Dialog & Europe & 218 & 297 & $36 \%$ & 527 & $77 \%$ \\
\hline 22 & 22 & 21 & Silicon Labs & U.S. & 441 & 494 & $12 \%$ & 492 & $0 \%$ \\
\hline 23 & 29 & 20 & MegaChips & Japan & 445 & 337 & $-24 \%$ & 456 & $35 \%$ \\
\hline 24 & 23 & 24 & Semtech & U.S. & 254 & 403 & $59 \%$ & 438 & $9 \%$ \\
\hline 25 & 24 & 23 & SMSC & U.S. & 283 & 397 & $40 \%$ & 415 & $5 \%$ \\
\hline \multicolumn{3}{|c|}{ Top 25 Total } & - & - & 38,242 & 47,733 & $25 \%$ & 52,076 & $9 \%$ \\
\hline \multicolumn{3}{|c|}{ Non-Top 25 Fabless } & - & - & 11,091 & 14,781 & $33 \%$ & 12,811 & $-13 \%$ \\
\hline \multicolumn{3}{|c|}{ Total Fabless } & - & - & 49,333 & 62,514 & $27 \%$ & 64,887 & $4 \%$ \\
\hline
\end{tabular}

\footnotetext{
${ }^{22}$ US: Qualcomm, Broadcom, Skyworks, TI, Freescale (ex-Motorola), Silicon labs, Agere. LSI. ADI, Intel.; Europe: NXP (ex Philips), STM, Infineon, Wavecom, TTPcom, Ericsson; Japan: NEC, Matsushita, Fujitsu, Renesas

${ }^{23}$ Qualcomm, Broadcom, Marvel, Intel (through acquisition of Infineon's wireless fablesss IC design division)

${ }^{24}$ Mega Chips is part of the Kawasaki Microelectronics, Inc. group.
} 
2011 Top 25 Fabless IC Suppliers Ranked by Growth Rate (\$M)

\begin{tabular}{|c|c|c|c|c|c|}
\hline $\begin{array}{r}2011 \\
\text { Rank }\end{array}$ & Company & Headquarters & $\begin{array}{l}2010 \\
\text { (SM) }\end{array}$ & $\begin{array}{l}2011 \\
(\$ M)\end{array}$ & $\begin{array}{c}\% \\
\text { Change }\end{array}$ \\
\hline $\begin{array}{l}1 \\
2 \\
3 \\
4 \\
5\end{array}$ & $\begin{array}{l}\text { Spreadtrum } \\
\text { Dialog } \\
\text { Qualcomm } \\
\text { MegaChips } \\
\text { LSI Corp. }\end{array}$ & $\begin{array}{l}\text { China } \\
\text { Europe } \\
\text { U.S. } \\
\text { Japan } \\
\text { U.S. }\end{array}$ & $\begin{array}{c}346 \\
297 \\
7,204 \\
337 \\
1,616\end{array}$ & $\begin{array}{c}674 \\
527 \\
9,910 \\
456 \\
2,042\end{array}$ & $\begin{array}{l}95 \% \\
77 \% \\
38 \% \\
35 \% \\
26 \%\end{array}$ \\
\hline 6 & MStar & Taiwan & 1,065 & 1,220 & $15 \%$ \\
\hline $\begin{array}{c}7 \\
8 \\
9 \\
10\end{array}$ & $\begin{array}{l}\text { Avago } \\
\text { Nvidia } \\
\text { HiSilicon } \\
\text { Semtech }\end{array}$ & $\begin{array}{c}\text { Singapore } \\
\text { U.S. } \\
\text { China } \\
\text { U.S. }\end{array}$ & $\begin{array}{l}1,187 \\
3,575 \\
652 \\
403\end{array}$ & $\begin{array}{c}1,341 \\
3,939 \\
710 \\
438\end{array}$ & $\begin{array}{l}13 \% \\
10 \% \\
9 \% \\
9 \%\end{array}$ \\
\hline $\begin{array}{l}11 \\
12 \\
13 \\
14 \\
15\end{array}$ & $\begin{array}{l}\text { Broadcom } \\
\text { Altera } \\
\text { CSR } \\
\text { Realtek } \\
\text { SMSC }\end{array}$ & $\begin{array}{l}\text { U.S. } \\
\text { U.S. } \\
\text { Europe } \\
\text { Taiwan } \\
\text { U.S. }\end{array}$ & $\begin{array}{c}6,589 \\
1,954 \\
801 \\
706 \\
397 \\
\end{array}$ & $\begin{array}{c}7,160 \\
2,064 \\
845 \\
742 \\
415 \\
\end{array}$ & $\begin{array}{l}\mathbf{9} \% \\
\mathbf{6} \% \\
\mathbf{5} \% \\
5 \% \\
5 \%\end{array}$ \\
\hline $\begin{array}{l}16 \\
17 \\
18 \\
19 \\
20\end{array}$ & $\begin{array}{l}\text { Novatek } \\
\text { PMC-Sierra } \\
\text { AMD } \\
\text { Silicon Labs } \\
\text { Himax }\end{array}$ & $\begin{array}{l}\text { Taiwan } \\
\text { U.S. } \\
\text { U.S. } \\
\text { U.S. } \\
\text { Taiwan }\end{array}$ & $\begin{array}{c}1,149 \\
635 \\
6,494 \\
494 \\
643\end{array}$ & $\begin{array}{c}1,198 \\
654 \\
6,568 \\
492 \\
633\end{array}$ & $\begin{array}{l}4 \% \\
3 \% \\
1 \% \\
0 \% \\
-2 \%\end{array}$ \\
\hline $\begin{array}{l}21 \\
22 \\
23 \\
24 \\
25\end{array}$ & $\begin{array}{l}\text { Xilinx } \\
\text { Lantiq } \\
\text { Marvell } \\
\text { MediaTek } \\
\text { ST-Ericsson* }\end{array}$ & $\begin{array}{l}\text { U.S. } \\
\text { Europe } \\
\text { U.S. } \\
\text { Taiwan } \\
\text { Europe }\end{array}$ & $\begin{array}{l}2,311 \\
550 \\
3,592 \\
3,590 \\
1,146\end{array}$ & $\begin{array}{c}2,269 \\
540 \\
3,445 \\
2,969 \\
825\end{array}$ & $\begin{array}{l}-2 \% \\
-2 \% \\
-4 \% \\
-17 \% \\
-28 \%\end{array}$ \\
\hline \multicolumn{3}{|c|}{ Top 25 Total } & 47,733 & 52,076 & $9 \%$ \\
\hline \multicolumn{3}{|c|}{ Non-Top 25 Fabless } & 14,781 & 12,811 & $-13 \%$ \\
\hline \multicolumn{3}{|c|}{ Total Fabless } & 62,514 & 64,887 & $4 \%$ \\
\hline
\end{tabular}

Source: Company reports, IC Insights' Str dogric Roviows Dotabaso 


\section{Upgrading Challenges and emerging strategies}

Chinese IC design firms are facing multiple challenges in their attempts to scale up, and to broaden and upgrade their IC design portfolio. It is useful to distinguish external and internal upgrading challenges. The former reflect fundamental transformations in the global wireless communications industry while the latter indicate limited technological and management capabilities of Chinese IC design companies.

Today, carriers and OEMs everywhere are requiring system-level integration on a chip in order to cope with the increasingly demanding performance requirements for electronic systems. At the same time, carriers and OEMs require drastic cost reduction of chips, and substantial improvements in the efficiency of their energy consumption. While these requirements are not new, the intensity of these requirements for chip design have substantially increased.

Over the last few years, the convergence of digital computing, communication and consumer devices has produced electronic systems that all strive to become lighter, thinner, shorter, smaller, faster and cheaper, as well as more multi-functional and less power-consuming. Essential performance features of mobile devices are expected to double every year or so, time-to-market is critical, and product-life-cycles are rapidly shrinking to a few months. Hence, time compression is essential in designing chips for such systems - chip design cycles of months or years are no longer acceptable.

At the same time, there is growing pressure to improve design productivity. A widening productivity gap between design and fabrication has been a primary driver behind these changes in design methodology. While the productivity of semiconductor fabrication has seen a 58\% compounded annual growth since the 1980s, the productivity of chip design has lagged behind, with only a $21 \%$ compounded annual rate. There is also an important time dimension to this gap, as rapid technology change shortens productlife-cycles. Manufacturing cycle times are measured in weeks, with low uncertainty. However, design and verification cycle times are measured in months or years, with high uncertainty. In the end, the design productivity gap reflects a growing mismatch between process and design technology -- the number of available transistors has grown faster than the ability to design them meaningfully. Miniaturization has resulted in chips of nano-meter feature size - with the current best practice process technology moving below 
$22 \mathrm{~nm}$. As a result, it is now possible to fabricate millions of transistors on a single chip. The resultant increase in design complexity must be matched by a dramatic improvement in design productivity, which requires significant changes in design methodology and organization.

Scaling-up is of the essence, in order to reap both economies of scale and economies of scope. Economies of scale are necessary to reduce the unit cost of each chip design. Economies of scope are at least equally important, as Chinese IC design firms now must address multiple market segments simultaneously. In wireless communications, Chinese IC design firms must sustain leadership in the lower-end feature phone markets which provide them with an important cash cow. At the same time, Chinese IC design firms must also penetrate new markets for higher-end products and processes. Economies of scale and scope are also necessary, as Chinese IC design firms must respond to integrated solutions "bundling" strategies of global market leaders with their own integrated "bundling" solutions.

Adding further to these upgrading challenges, Chinese IC design firms must adjust their strategy and organization in a competitive environment that is characterized by market consolidation through $\mathrm{M} \& \mathrm{~A}$ and strategic partnerships. An equally important challenge results from shrinking margins due to unanticipated disruptive technical change which reflects the rising complexity of wireless communication technology and its markets and its industry structure.

Arguably the most important challenge for upgrading and innovation strategies of Chinese IC design firms in wireless communications is that intellectual property has become a critical determinant of competitive success $-21 \%$ of all patents granted in the US in 2011 are related to wireless communications ${ }^{25}$. What matters in particular is the persistent concentration of patent ownership, with China still being a marginal actor.The top 20 global patent leaders in mobile communications control one third of the overall mobile patent pool. China's leading telecom equipment vendors have increased their international patent applications - in 2010, ZTE was No.2 in WIPO's Patent Cooperation

\footnotetext{
${ }^{25}$ Derwent Worldwide Patent Data Base 2012
} 
Treaty (PCT) Applications, and Huawei was No. $4^{26}$. However, no other Chinese company is among the top 100 applicants, and China keeps lagging way behind the US in terms of the overall volume of wireless communications patent applications.

The gap is even larger for patents that are essential for the new 4G LTE wireless communications standard. A recent study shows that Nokia, Qualcomm, Samsung and Ericsson have built the strongest LTE patent portfolios while also taking a leadership position in future LTE technologies ${ }^{27}$. In addition, the recent acquisitions of the patent portfolios of Nortel and Motorola Mobility at $\$ 4.5 \mathrm{~B}$ and $\$ 12.5 \mathrm{~B}$ respectively have given Apple, Microsoft, Google and RIM a strong position in patent ownership of LTE technology.

China's position in LTE essential patents is still very weak. Of the 3,107 patents and pending patents declared as essential for the LTE standard by the ETSI in September 2011, Huawei had 116 (i.e. $3.73 \%$ of the total)and ZTE 84 ( $2.7 \%$ ) such patents - hardly enough to compete on an equal footing.

To cope with the above upgrading barriers, Chinese IC design companies need to introduce in a timely manner new product and process technologies. But Chinese IC design companies are facing fundamental challenges in their attempts to expand their inhouse R\&D. The low margins that Chinese IC design companies can reap in their cash cow markets for feature phone handsets are limiting the funds available for in-house $R \& D$. While smart phone markets are now increasing in importance, much of that market in China will be for low-cost budget smart phones, which again may lead to low and sometimes even razor-thin profit margins. In addition, IC design companies are under tremendous pressure to respond quickly to new technologies and abruptly changing demand patterns. This implies that in-house R\&D is not a very practical option, as it would take too much time.

Finally, as newcomers to the wireless IC design field, Chinese IC design firms face serious problems in gaining "design-ins". First-tier handset makers typically prefer

\footnotetext{
${ }^{26}$ WIPO Patent Data Base. WIPO's Patent Cooperation Treaty (PCT) provides a unified procedure for filing patent applications to protect inventions in each of its contracting states.

${ }^{27}$ Article One Partners, 2012, LTE Standard Essential Patents Now and in the Future, http://newsletters.articleonepartners.com/news_4296e045-efdc-f819-c332f181a6d2e012LTE\%20Standard\%20Essential\%20Patents\%20Now\%20and\%20in\%20the\%20Future AOP. pdf
} 
proven designs by leading IC design companies, like Qualcom, rather risking the success of their handsets with largely unproven designs from Chinese firms. In short, global technology sourcing is a must for Chinese IC design firms if they want to scale up and upgrade quickly into more profitable higher-end products and processes. Our interviews show that leading Chinese IC design companies are heavily relying on global technology sourcing.

\section{Diverse approaches to global technology sourcing - Preliminary findings from interviews with one Chinese smart phone vendor, and two fabless Chinese IC design companies.}

It is most striking that the leading Chinese designers of ICs for handsets have responded to this opportunity with dramatically different business and technology strategies. Each of these business strategies depends on a particular approach to global technology sourcing, which in turn is tailored to that business strategy. ${ }^{28}$ While the business strategies are very different, they imply that the companies will be in intensified competition with each other as the market for smart phones in China explodes; as lowcost smart phones hit the market; and as feature phones with smart-phone like features are developed. Differences in strategy, combined with a huge and rapidly growing market, may make it possible for many of these firms to thrive simultaneously by occupying slightly different market niches. However, the firms are very aware that they are coming into increasingly direct competition with each other, and that it is very likely that only a few of these companies will survive, and the others will be washed away by the force of competition.

A simplified breakdown of business strategies of three of the leading firms is as follows:

Xiaomi ["Millet"]. Xiaomi is sometimes called the "Apple of China" because of its stylish, multi-colored, powerful smart phones. The title is not precise, but it gives a flavor of Xiaomi's strategy. Xiaomi's business strategy relies on being first to market with a fast, high quality smartphone that is affordable. Selling smartphones for RMB 1,999 - a price which, given discounts and various other pressures is being forced down

\footnotetext{
${ }^{28}$ Future research will explore, for a larger sample of Chinese IC design companies, the possible implications of their heavy use of design tools and design IP.
} 
toward 1,499 - the company has quickly established a market presence among consumers in big cities. ${ }^{29}$

Global sourcing: Uniquely among our respondents, Xiaomi uses top quality components from global firms, including Qualcomm processors, memory from Samsung, and Sharp screens. Then, Xiaomi's engineers do everything else in house, including integration of these components, hardware design and software design and integration. In addition, Xiaomi's strategy, like many firms in China, is founded on availability of the open-source Android OS from Google. Xiaomi is the most reliant on global technology sourcing of all the companies we visited.

Discussion: Xiaomi's strategy is centered around the conviction that control of the software interface provides the greatest long-run profit opportunity. Thus, their strategy is to forgo hardware profits in order to establish a dominant position as provider of internet services through software superiority, which can be monetized later. Xiaomi has some very innovative practices, including posting weekly software updates online, and soliciting user comment, enabling super-fast tweaking and optimization.

RDA. RDA is following a strategy that is in some sense the most "traditional" late-comers catch-up strategy. RDA produces chips that are cheaper, and while not as advanced as the cutting-edge producers, they provide excellent features and functionality for price. Moreover, they are able to work with customers to provide a high level of integration among components and customized solutions. RDA has a large market share in China with inexpensive handset producers, including so-called shanzhai producers, and those that export inexpensive phones to developing Asia and Africa. RDA first established itself with a good quality, cheap Bluetooth chip, and developed capabilities from there. The formal acquisition of Coolsand in February 2012, completed the process of RDA developing its own baseband chips, which in turn enables them to offer packaged

\footnotetext{
${ }^{29}$ Recall that in China, unlike in the US, phone carriers do not generally subsidize handset prices by bundling them with long-term service contracts. Most Chinese consumers are used to paying full price for handsets, meaning that a new model iPhone sells for about 5,000 RMB. At the current exchange rate of 6.3 RMB to the dollar, this means an iPhone sells for almost $\$ 800$, while the Xiaomi was introduced at $\$ 317$, and is now available for $\$ 238$. To be able to buy a good quality smartphone for $\$ 200$ and plug it into cheap, flexible networks (including choice of different payment arrangements) is something American consumers can only dream of.
} 
solutions. ${ }^{30}$ RDA with Coolsand shipped their first baseband chips in 2011 and are now number 3 in the GSM baseband chip market after Mediatek and Spreadtrum. They will have a $3 \mathrm{G}$ baseband chip in the first half of 2013, allowing them to support the smartphone market, but later than Mediatek or Spreadtrum.

Global sourcing: RDA's strategy of cost minimization requires an exceptionally careful and focused global technology sourcing strategy. The price of global technology matters to RDA a great deal, as they must minimize total non-recurring costs. RDA licenses a great deal of IP, including prominently ARM cores and the core IP for wifi. They work closely with ED suppliers such as Synopsis. However, these are far from "turn-key" operations. RDA licenses blocks of IP and then encourages their engineers to invest substantial time and effort to understand that IP. Engineers are encouraged to prototype early, producing a chip which the company then debugs itself. Faster prototyping leads to quicker learning. The cost of sending tape-outs (prototypes) to the fab is considered good value for the rapid learning it produces. RDA is not dependent on global foundries, since it is currently designing at $60 \mathrm{~nm}$ (and has products using from 110 to $55 \mathrm{~nm}$ ), so they are able to use a range of foundries, predominantly within China.

Discussion: RDA's strategy relies on access to cheap, well-trained engineering talent. These engineers have graduated from Chinese universities, and RDA willingly takes on the task of providing them with real-world experience. Through intensive use of domestic engineering talent, RDA engages in exceptionally rapid cycles of prototyping and new product development. This has allows rapid catch-up in capabilities and a sustained growth in market share at the low end of the end market.

Spreadtrum (zhanxun). Spreadtrum is a rapidly-growing mid-size firm that has a large share of the TD-SCDMA market in China. Following a path initially blazed by Taiwan firm Mediatek, Spreadtrum aims to provide a turnkey platform that combines

\footnotetext{
${ }^{30}$ From Wikipedia: "A baseband processor (BP) is a device (a chip or part of a chip) in a network interface that manages all the radio functions (all functions that require an antenna). This may not include wi-fi and/or bluetooth. It typically uses its own RAM and firmware. The rationale of separating the baseband processor from the main processor (known as the AP or Application Processor) is threefold: (1) radio control functions are highly timing dependant, and require a real time Operating System; (2) legal: some authorities require that the entire communications software stack be certified. Separating the BP into a different component allows reusing them without having to certify the full AP; (3) radio reliability: Separating the BP into a different component ensures proper radio operation while allowing application and OS changes. Baseband processors typically run a real time operating system written in firmware.
} 
baseband and RF (radio frequency) chips, along with all the relevant associated software solutions (including protocol stack, SW platform, and multimedia and internet interfaces). Beginning as a low-cost copycat of Mediatek's comprehensive solutions for low-end feature phones, Spreadtrum has followed a remarkable process of technology leapfrogging, moving rapidly to implement near leading-edge process technology, which has enabled it to offer feature-rich phones and move rapidly into the smartphone era. A key milestone came in October 2010, when Spreadtrum engineers successfully prototyped a $2.5 \mathrm{G}$ integrated chip solution using $40 \mathrm{~nm}$ process technology, which provided the basis for a $95 \%$ increase in sales in 2011. The company is now planning for a transition to $28 \mathrm{~nm}$ process technology during 2012.

Global sourcing: Spreadtrum is a major user of global technology resources. Spreadtrum has greater resources than RDA to spend in acquiring IP cores and design blocks from global suppliers such as Synopsis. The ability of Spreadtrum to efficiently access and utilize these resources is a key part of its success. Even more striking, though, in Spreadtrum's case, is the close cooperation with Taiwan Semiconductor (TSMC) which has enabled Spreadtrum to shrink the gap with the process technology global frontier. According to Spreadtrum's own account, TSMC prioritizes cooperation with two fablesss IC design companies in telecom, and these are Qualcomm and Spreadtrum. TSMC cooperation is alleged by competitors to have been a key enabling factor in Spreadtrum's astonishing success in skipping a generation and successfully prototyping — on the first try - a $40 \mathrm{~nm}$ integrated solution (baseband +) in 2010. Subsequently, this sustained relative advantage in process technology has given Spreadtrum the ability to move to new performance levels as it can producer smaller more efficient chips with a greater range of capabilities.

Discussion: Spreadtrum's strategy places it squarely in the center of the emerging Chinese market for smartphones, and particularly those based on TS-SCDMA, in which it is dominant. In current market conditions, Spreadtrum has been able to consolidate and expand its presence in a wide range of market segments, extending from mid-tier feature phones, through the new smart phone market, and up to current development of phones that will provide multi-mode functions in the future 4 G LTE markets. During the second 
half of 2012, Spreadtrum is ramping up sales of true $3 \mathrm{G}$ smartphone chips, and expects to sell 15-20 million.

\section{Conclusions}

This paper highlights a fundamental challenge for China's innovation strategy: How can China reconcile its primary objective of strengthening indigenous innovation with the benefits that it could reap from its deep integration into international trade and into global networks of production and innovation?

As vertical specialization disintegrates the global semiconductor value chain, latecomers like China can now "source" technological knowledge and services from a growing variety of sources. We demonstrate that global technology sourcing is necessary for the success of the upgrading strategies of Chinese wireless IC design firms. We also highlight stages of IC design where global technology sourcing is of critical importance, and describe the great variety of technology sourcing arrangements that are emerging in this industry.

The paper explores how tectonic shifts in the global telecommunications industry provide new entry possibilities for Chinese IC design firms. An important finding is that disruptive changes in the global semiconductor value chain that started with seemingly small discrete steps can completely upset the existing competitive order. We show how entry barriers were driven down when Mediatek of Taiwan introduced inexpensive system-on-chip solutions, enabling China's whitebox ("Shanzhai") makers to penetrate into China's thriving budget smart phone market. This disruption is about to happen again, as China belatedly enters third generation (3G) mobile telecommunications, and prepares its foray into fourth generation $(4 \mathrm{G})$ technologies. The result is intensifying competition, with domestic and global players rushing to bring out new chips, and pushing the envelope on process technology. This process culminates in the development of new hybrid business models that rely heavily on global technology sourcing.

These findings have important policy implications. They support our argument, advanced a few years ago, that innovation in China progresses in areas that escape the attention of both pessimists (who emphasize China's weak innovation capacity) and 
proponents of an emerging new technology superpower ${ }^{31}$. This paper shows an innovative China that is deeply integrated into global production and innovation networks; uses sophisticated global technology sourcing strategies; and quickly responds to changes in the global division of labor. And Taiwan plays an important role in many of those technology-sourcing links.

Global technology sourcing describes a small but important segment of China's innovation system that is very different from the government-sponsored innovation of the strategic emerging industries and "indigenous innovation." These two faces of “innovative China" coexist, but so far with little interaction. This raises an important question for China's innovation strategy: Is China adequately accounting for the unintended costs of "indigenous innovation", and can China combine the benefits of both innovation strategies?

\footnotetext{
${ }^{31}$ Ernst, D. and B. Naughton, 2008, "China's Emerging Industrial Economy - Insights from the IT Industry", in C. McNally, editor, China's Emergent Political Economy - Capitalism in the Dragon's Lair, Routledge, Milton Park and New York; and Ernst, D., 2008, "Can Chinese IT Firms Develop Innovative capabilities within Global Knowledge Networks?”, in H.S. Rowen, M.G. Hancock, and W.F. Miller, 2008, China's Quest for Independent Innovation, Shorenstein Asia Pacific Research Center and Brookings Institution Press
} 